\title{
Induced Daldinin A, B, C with a New Skeleton from Cultures of the Ascomycete Daldinia concentrica
}

\author{
Hong-Jun Shao, Xiang-Dong Qin, Ze-Jun Dong, Hong-Bin Zhang, Ji-Kai Liu
}

Received: November 29, 2007 / Accepted: February 25, 2008

(C) Japan Antibiotics Research Association

\begin{abstract}
Daldinin A, B, C with a new skeleton, together with four known compounds, were induced and isolated from cultures of the ascomycete Daldinia concentrica. Their structures were elucidated by spectroscopic analysis, and that of daldinin A was confirmed by single-crystal Xray diffraction.
\end{abstract}

Keywords daldinin A, daldinin B, daldinin C, Daldinia concentrica, ascomycete, induction

\section{Introduction}

Natural products are an attractive source of varied structures that exhibit potent biological activities, and desirable pharmacological profiles. Historically, natural products have been the source of many new drugs. Their importance is well documented in the recent literatures [1 3]. The search for bioactive compounds is one of the central subjects of industrial and academic natural products chemistry. With new emerging targets for drug discovery, continued demand for new diverse natural products serve as a vehicle for probing biological activity.

Variation of cultivation parameters to induce the production of formerly unknown compounds is the most simple approach to increase the number of secondary metabolites from one single organism for fungi or bacteria. This way of releasing nature's chemical diversity was

J.-K. Liu (Corresponding author), H.-J. Shao, X.-D. Qin, Z.-J. Dong: State Key Laboratory of Phytochemistry and Plant Resources in West China, Kunming Institute of Botany, Chinese Academy of Sciences, Kunming 650204, China,

E-mail: jkliu@mail.kib.ac.cn

H.-B. Zhang: Yunnan University, Kunming 650091, China termed the 'OSMAC (One Strain-Many Compounds)' approach [4, 5]. It is based on the observation that individual strains are able to produce more metabolites than normally detected in a routine screening program and very small changes in the cultivation parameters (for example, culture vessel, media composition, addition of enzyme inhibitors) can completely shift the metabolic profile of various microorganisms. It is a very simple but even more random approach to the improvement of fermentations to obtain maximum production titers of desired compounds. This approach was successfully used as a valuable tool to exploit natural products diversity in the past, for example, actinomycetes (Streptomyces sp.) and fungi (Aspergillus sp., Sphaeropsidales sp.) produce additional compounds after variation of the culture conditions [6 8].

As shown in former investigations, an anti-HIV-1 agent concentricolide (4) and other six new compounds were isolated from the fruiting bodies of Daldinia concentrica [9 13]. Concentricolide showed an activity to inhibit HIV-1 induced cytopathic effects. The $\mathrm{EC}_{50}$ value was $0.31 \mu \mathrm{g} / \mathrm{ml}$. The therapeutic index (TI) was 247 . Concentricolide exhibited the blockage $\left(\mathrm{EC}_{50} 0.83 \mu \mathrm{g} / \mathrm{ml}\right)$ on syncytium formation between HIV-1 infected cells and normal cells. Daldinia concentrica (strain S 0318) produces concentricolide and a pair of novel hept-6-ene2,4,5-triols when cultivated in reagent bottles (color: brown; size: $500 \mathrm{ml}$; volume of medium: $300 \mathrm{ml}$ ) with cultivation medium (PD): potato (peel off) $200 \mathrm{~g}$, glucose $20 \mathrm{~g}, \mathrm{KH}_{2} \mathrm{PO}_{4} 3.0 \mathrm{~g}, \mathrm{MgSO}_{4} 1.5 \mathrm{~g}$, citric acid $0.1 \mathrm{~g}$ and thiamin hydrochloride $10 \mathrm{mg}$ in 1.0 liter of de-ionized water. Applying the OSMAC approach, we intended to examine whether the production of new metabolites could be induced in this strain.

Following the OSMAC approach, our strain S 0318 has been cultivated with Erlenmeyer flask instead of reagent 


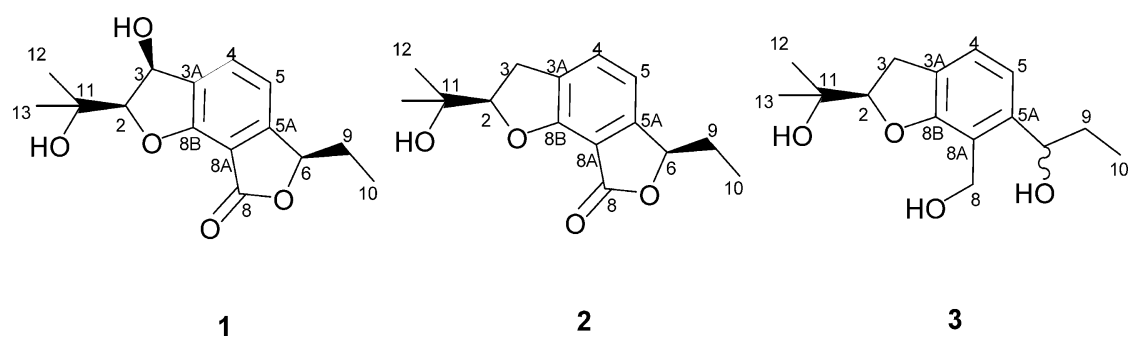

Structures of daldinin A (1), daldinin B (2), daldinin C (3)

bottles. The surprises were obtained. In the culture broth extract from Erlenmeyer flasks (color: white; size: $500 \mathrm{ml}$; media: $300 \mathrm{ml}$ ) we detected, by thin layer chromatography and HPLC, rich additional metabolites besides concentricolide. Careful investigation on the culture of $D$. concentrica strain (S 03180) led to the isolation of new compounds daldinins $\mathrm{A} \sim \mathrm{C}(\mathbf{1} \sim \mathbf{3})$ and known compounds: concentricolide (4) [9], isoochracein (5) [14], 4hydroxyisoochracein (6) [15] and 2-(hydroxymethyl)-3-(1'hydroxypropyl) phenol (7) [16] by the alteration of culture parameter (form of culture vessel). The fermentation, isolation and structure elucidation of theses compounds are reported here.

\section{Materials and Methods}

\section{General}

NMR experiments were performed on a Bruker AM-400 or a DRX-500 spectrometer with TMS as internal standard. Mass spectra were recorded on a VG Auto Spec-3000 or an API QSTAR Pulsar 1 spectrometer. IR spectra were recorded on a Bruker Tensor 27 spectrometer with $\mathrm{KBr}$ pellets. Optical rotations were measured on a Horiba SEPA300 polarimeter. Column chromatography was performed on silica gel (200 300 mesh; Qingdao Marine Chemical Ltd., Qingdao, People's Republic of China) and Sephadex LH-20 (Amersham Biosciences, Sweden). TLC analysis was carried out on silica gel GF254 precoated plates $(0.20 \sim 0.25 \mathrm{~mm}$; Qingdao) with detection by heating silica gel plates sprayed with $10 \% \mathrm{H}_{2} \mathrm{SO}_{4}$ in $\mathrm{EtOH}$.

\section{Fungal Material}

Strain (S 0318) was isolated from tissue culture of the fruiting bodies of Daldinia concentrica collected at Laojunshan, Yunnan Province, P. R. China, in July 2003 and identified by Prof. Mu Zang, Kunming Institute of Botany, Chinese Academy of Sciences. A voucher specimen (HKAS 40992) was deposited at the herbarium of Kunming Institute of Botany, Chinese Academy of Sciences.

\section{Cultivation}

Strain S 0318 was grown on agar slopes at $22^{\circ} \mathrm{C}$ until sporulation, and then stored at $4^{\circ} \mathrm{C}$. The culture medium consisted of potato (peel off) $200 \mathrm{~g}$, glucose $20 \mathrm{~g}, \mathrm{KH}_{2} \mathrm{PO}_{4}$ $3.0 \mathrm{~g}, \mathrm{MgSO}_{4} 1.5 \mathrm{~g}$, citric acid $0.1 \mathrm{~g}$ and thiamin hydrochloride $10 \mathrm{mg}$ in 1.0 liter of de-ionized water. The fungus was grown in Erlenmeyer flasks (color: white; size: $500 \mathrm{ml}$; media: $300 \mathrm{ml}$ ). The $\mathrm{pH}$ was adjusted to 6.5 before autoclaving. Fermentation was carried out on a rotary shaker at $22^{\circ} \mathrm{C}$ and $150 \mathrm{rpm}$ for 10 days.

\section{Extraction and Isolation}

The mycelium from 60 liters was filtered, and the filtrate was extracted five times with EtOAc (total 80 liters). The EtOAc extract was evaporated in vacuo and the deep brown gum $(80 \mathrm{~g})$ was subjected to column chromatography (silica gel) using a $\mathrm{CHCl}_{3} / \mathrm{MeOH}$ gradient elution. Elution with $\mathrm{CHCl}_{3} / \mathrm{MeOH}(98: 2$, v/v) produced $4(20 \mathrm{mg})$, and $5(17 \mathrm{mg})$. The fraction $(20 \mathrm{~g})$ from $\mathrm{CHCl}_{3} / \mathrm{MeOH}$ $(95: 5)$ was further purified by twice chromatography over silica gel (petroleum ether/ $\mathrm{Me}_{2} \mathrm{CO}$, from $20: 1$ to $10: 1$; $\mathrm{CHCl}_{3} / \mathrm{MeOH}$, from $30: 1$ to $10: 1$ ), and repeated Sephadex $\mathrm{LH}-20\left(\mathrm{CHCl}_{3} / \mathrm{MeOH}, 1: 1\right)$ to afford the pure compounds $2(63 \mathrm{mg})$, and $6(46 \mathrm{mg})$. The fraction $(24 \mathrm{~g})$ eluted with $\mathrm{CHCl}_{3} / \mathrm{MeOH}(90: 10)$ at the first chromatography was also further purified by repeated chromatography over silica gel $\left(\mathrm{CHCl}_{3} / \mathrm{MeOH}\right.$, from $20: 1$ to $\left.5: 1\right)$ to yield compounds 1 (7 mg), 3 (60 mg), and 7 (87 mg).

\section{Physico-chemical Properties}

Daldinin A (1). Colorless prisms; m.p. 228 229 (C; $[\alpha]_{\mathrm{D}}^{26}$ $-44.2^{\circ}$ (c 0.39 in $\mathrm{MeOH}$ ); IR (KBr): $v_{\max } 3258,1760$, $1633,1607,1475,1452 \mathrm{~cm}^{-1}$; UV $(\mathrm{MeOH}): \lambda_{\max }(\log \varepsilon)$ 209 (4.48), 217 (4.43), 306 (3.83), 359 (2.56) nm; ${ }^{1} \mathrm{H}-$ and ${ }^{13} \mathrm{C}$-NMR data: see Table 1; EI-MS $\mathrm{m} / \mathrm{z}$ (relative intensity) $[\mathrm{M}]^{+} 278$ (1), 203 (94), 185 (41), 173 (100), 145 (83); Negative FAB-MS $m / z$ (relative intensity) $[\mathrm{M}-\mathrm{H}]^{-}$ 277(100); HR-ESI-MS $m / z[\mathrm{M}+\mathrm{Na}]^{+} 301.1049$ (calcd for $\left.\mathrm{C}_{15} \mathrm{H}_{18} \mathrm{O}_{5} \mathrm{Na}, 301.1051\right)$. 
Table 1 NMR spectral data for daldinin $A(\mathbf{1})$ in $\mathrm{CD}_{3} \mathrm{OD}$

\begin{tabular}{|c|c|c|c|c|}
\hline & ${ }^{13} \mathrm{C}$ & ${ }^{1} \mathrm{H}$ & ${ }^{1} \mathrm{H},{ }^{1} \mathrm{H}-\mathrm{COSY}$ & $\mathrm{HMBC}$ \\
\hline 2 & 94.0 & $4.46(1 \mathrm{H}, \mathrm{d}, 6.3)$ & $\mathrm{H}-3$ & $\mathrm{C}-3 \mathrm{~A}, 8 \mathrm{~B}, 12,13$ \\
\hline 3 & 71.9 & $5.37(1 \mathrm{H}, \mathrm{d}, 6.3)$ & $\mathrm{H}-2$ & $C-4,8 B, 11$ \\
\hline $3 A$ & 133.4 & & & \\
\hline 4 & 133.5 & $7.70(1 \mathrm{H}, \mathrm{d}, 7.6)$ & $\mathrm{H}-5$ & $C-3,5 A, 8 B$ \\
\hline 5 & 115.2 & $7.06(1 \mathrm{H}, \mathrm{d}, 7.6)$ & $\mathrm{H}-4$ & $\mathrm{C}-3 \mathrm{~A}, 6,8 \mathrm{~A}$ \\
\hline $5 A$ & 154.2 & & & \\
\hline 6 & 84.3 & $5.51(1 \mathrm{H}, \mathrm{dd}, 4.1,6.8)$ & $\mathrm{H}-9$ & $\mathrm{C}-5,5 \mathrm{~A}, 8,8 \mathrm{~A}, 10$ \\
\hline 8 & 170.4 & & & \\
\hline $8 \mathrm{~A}$ & 110.2 & & & \\
\hline $8 B$ & 158.7 & & & \\
\hline 9 & 28.7 & $1.81(1 \mathrm{H}, \mathrm{m}) 2.14(1 \mathrm{H}, \mathrm{m})$ & $\mathrm{H}-6,10$ & $C-5 A, 6,10$ \\
\hline 10 & 8.8 & $0.95(3 \mathrm{H}, \mathrm{t}, 7.4)$ & $\mathrm{H}-9$ & $C-6,9$ \\
\hline 11 & 73.2 & & & \\
\hline 12 & 26.5 & $1.50(3 \mathrm{H}, \mathrm{s})$ & & $C-2,11,13$ \\
\hline 13 & 27.0 & $1.48(3 \mathrm{H}, \mathrm{s})$ & & $\mathrm{C}-2,11,12$ \\
\hline
\end{tabular}

Table 2 NMR spectral data for daldinin $\mathrm{B}(\mathbf{2})$ in $\mathrm{CD}_{3} \mathrm{OD}$

\begin{tabular}{|c|c|c|c|c|}
\hline & ${ }^{13} \mathrm{C}$ & ${ }^{1} \mathrm{H}$ & ${ }^{1} \mathrm{H},{ }^{1} \mathrm{H}-\mathrm{COSY}$ & $\mathrm{HMBC}$ \\
\hline 2 & 92.6 & $4.48(1 \mathrm{H}, \mathrm{dd}, 8.8,9.3)$ & $\mathrm{H}-3$ & $\mathrm{C}-3 \mathrm{~A}, 8 \mathrm{~B}, 12,13$ \\
\hline \multirow[t]{2}{*}{3} & 29.8 & $3.17(1 \mathrm{H}, \mathrm{dd}, 9.7,16.1)$ & $\mathrm{H}-2$ & $\mathrm{C}-4,8 \mathrm{~B}, 11$ \\
\hline & & $3.25(1 \mathrm{H}, \mathrm{dd}, 8.8,16.1)$ & & \\
\hline $3 A$ & 130.3 & & & \\
\hline 4 & 131.3 & $7.44(1 \mathrm{H}, \mathrm{d}, 7.4)$ & $\mathrm{H}-5$ & $\mathrm{C}-3,5 \mathrm{~A}, 8 \mathrm{~B}$ \\
\hline 5 & 113.6 & $6.89(1 \mathrm{H}, \mathrm{d}, 7.4)$ & $\mathrm{H}-4$ & $\mathrm{C}-3 \mathrm{~A}, 6,8 \mathrm{~A}$ \\
\hline $5 \mathrm{~A}$ & 150.8 & & & \\
\hline 6 & 82.4 & $5.34(1 \mathrm{H}, \mathrm{dd}, 4.4,6.8)$ & $\mathrm{H}-9$ & $\mathrm{C}-5,5 \mathrm{~A}, 8,8 \mathrm{~A}, 10$ \\
\hline 8 & 168.2 & & & \\
\hline $8 \mathrm{~A}$ & 108.8 & & & \\
\hline $8 \mathrm{~B}$ & 158.4 & & & \\
\hline 9 & 29.3 & $1.67(1 \mathrm{H}, \mathrm{m}), 2.01(1 \mathrm{H}, \mathrm{m})$ & H-6, 10 & $C-5 A, 6,10$ \\
\hline 10 & 9.0 & $0.88(3 \mathrm{H}, \mathrm{t}, 7.3)$ & $\mathrm{H}-9$ & $C-6,9$ \\
\hline 11 & 71.3 & & & \\
\hline 12 & 25.6 & $1.26(3 \mathrm{H}, \mathrm{s})$ & & $C-2,11,13$ \\
\hline 13 & 25.5 & $1.19(3 \mathrm{H}, \mathrm{s})$ & & $\mathrm{C}-2,11,12$ \\
\hline
\end{tabular}

Crystallographic Data for $\mathbf{1}$

$\mathrm{C}_{15} \mathrm{H}_{18} \mathrm{O}_{5}, \quad M 278.30$, orthorhombic, space group $P 2{ }_{1}{ }_{1}{ }_{1}{ }_{1}, a=8.245$ (1) $\AA, b=11.153$ (1) $\AA, c=15.784$ (1) $\AA$, $V=1451.4(2) \AA^{3}, Z=4$, crystal dimensions $0.20 \times 0.40 \times$ $0.60 \mathrm{~mm}$ were used for measurements on a MAC DIP$2030 \mathrm{~K}$ diffractometer with a graphite monochromator $\left(\omega-2 \theta\right.$ scans, $\left.2 \theta_{\max }=50.0^{\circ}\right)$, Mo $\mathrm{K} \alpha$ radiation. The total number of independent reflections measured was 1517, of which 1407 were observed $\left(|F|^{2} \geq 2 \sigma|F|^{2}\right)$. Final indices: $R_{1}=0.058, w R_{2}=0.165$. The crystal structure of 1 was solved by direct methods using SHELXS-97 and expanded using difference Fourier techniques, refined by the program and method NOMCSDP and full-matrix least-squares calculations. The crystal structure of $\mathbf{1}$ was solved by direct methods using SHELXS-97 and expanded using difference Fourier techniques, refined by the program and method NOMCSDP and full-matrix least-squares calculations.

Daldinin B (2). Light yellow, oily solid; $[\alpha]_{\mathrm{D}}^{19}-26.6^{\circ}$ (c 0.60 in $\mathrm{Me}_{2} \mathrm{CO}$ ); IR (KBr): $v_{\max } 3445,1755,1633,1607$, $1480,1450 \mathrm{~cm}^{-1}$; UV (MeOH): $\lambda_{\max }(\log \varepsilon) 212$ (4.21), 218 
Table 3 NMR spectral data for daldinin $\mathrm{C}(\mathbf{3})$ in $\mathrm{CD}_{3} \mathrm{OD}$

\begin{tabular}{|c|c|c|c|c|}
\hline & ${ }^{13} \mathrm{C}$ & ${ }^{1} \mathrm{H}$ & ${ }^{1} \mathrm{H},{ }^{1} \mathrm{H}-\mathrm{COSY}$ & $\mathrm{HMBC}$ \\
\hline 2 & 90.2 & $4.58(1 \mathrm{H}, \mathrm{dd}, 8.5,9.4)$ & $\mathrm{H}-3$ & C-3A, 8B, 12, 13 \\
\hline \multirow[t]{2}{*}{3} & 31.4 & $3.10(1 \mathrm{H}, \mathrm{dd}, 9.6,16.0)$ & $\mathrm{H}-2$ & $\mathrm{C}-4,8 \mathrm{~B}, 11$ \\
\hline & & $3.25(1 \mathrm{H}, \mathrm{dd}, 8.5,16.0)$ & & \\
\hline $3 \mathrm{~A}$ & 127.0 & & & \\
\hline 4 & 125.3 & $7.09(1 \mathrm{H}, \mathrm{d}, 7.6)$ & $\mathrm{H}-5$ & $\mathrm{C}-3,5 \mathrm{~A}, 8 \mathrm{~B}$ \\
\hline 5 & 119.2 & $6.95(1 \mathrm{H}, \mathrm{d}, 7.6)$ & $\mathrm{H}-4$ & $\mathrm{C}-3 \mathrm{~A}, 6,8 \mathrm{~A}$ \\
\hline $5 A$ & 144.4 & & & \\
\hline 6 & 72.7 & $4.88(1 \mathrm{H}, \mathrm{dd}, 6.3,7.2)$ & $\mathrm{H}-9$ & $C-5,5 A, 8 A, 10$ \\
\hline 8 & 58.7 & $4.71(2 \mathrm{H}, \mathrm{s})$ & & \\
\hline $8 \mathrm{~A}$ & 120.0 & & & \\
\hline $8 \mathrm{~B}$ & 159.8 & & & \\
\hline 9 & 32.4 & $1.77(2 \mathrm{H}, \mathrm{m})$ & $\mathrm{H}-6,10$ & $C-5 A, 6,10$ \\
\hline 10 & 11.0 & $0.94(3 \mathrm{H}, \mathrm{t}, 7.4)$ & $\mathrm{H}-9$ & $C-6,9$ \\
\hline 11 & 72.6 & & & \\
\hline 12 & 24.8 & $1.20(3 \mathrm{H}, \mathrm{s})$ & & $C-2,11,13$ \\
\hline 13 & 25.7 & $1.30(3 \mathrm{H}, \mathrm{s})$ & & $\mathrm{C}-2,11,12$ \\
\hline
\end{tabular}

(4.44), 314 (3.79) nm; ${ }^{1} \mathrm{H}$ - and ${ }^{13} \mathrm{C}-\mathrm{NMR}$ data: see Table 2; EI-MS $m / z$ (relative intensity) $[\mathrm{M}]^{+} 262(24),\left[\mathrm{M}-\mathrm{CH}_{3}\right]^{+}$ 247 (8), $\left[\mathrm{M}-\mathrm{CH}_{3}-\mathrm{H}_{2} \mathrm{O}\right]^{+} 229$ (31), 215 (10), 204 (72), 186 (100), 175 (55), 171 (60), 158 (88), 145 (30), 129 (14); HR-ESI-MS $\mathrm{m} / \mathrm{z}[\mathrm{M}+\mathrm{Na}]^{+} 285.1099$ (calcd for $^{+}$ $\left.\mathrm{C}_{15} \mathrm{H}_{18} \mathrm{O}_{4} \mathrm{Na}, 285.1102\right)$.

Daldinin C (3). Oily solid; $[\alpha]_{\mathrm{D}}^{25}-2.2^{\circ}$ (c 0.46 in $\mathrm{MeOH}) ; \quad$ IR (KBr): $v_{\max }$ 3384, 1712, 1623, 1595, $1443 \mathrm{~cm}^{-1}$; UV (MeOH): $\lambda_{\max }(\log \varepsilon) 206$ (4.53), 292 (3.59) nm; ${ }^{1} \mathrm{H}$ - and ${ }^{13} \mathrm{C}-\mathrm{NMR}$ data: see Table 3; EI-MS $\mathrm{m} / \mathrm{z}$ (rel intensity) [M] ${ }^{+} 266$ (7), 248 (1), 233 (2), 219 (97), 201 (19), 190 (22), 172 (75), 157 (100), 133 (46), 105 (11), 91 (13), 77 (14); Negative FAB-MS $m / z$ (relative intensity) $[\mathrm{M}-\mathrm{H}]^{-} 265$ (100); HR-ESI-MS $m / z[\mathrm{M}-\mathrm{H}]^{-} 265.1439$ (calcd for $\mathrm{C}_{15} \mathrm{H}_{21} \mathrm{O}_{4}, 265.1439$ ).

\section{Results and Discussion}

Daldinin A (1) was obtained as colorless prisms. Its molecular formula was found to be $\mathrm{C}_{15} \mathrm{H}_{18} \mathrm{O}_{5}$ by mass spectrometry and confirmed by HR-ESI-MS (found 301.1049, calcd for $\left.\mathrm{C}_{15} \mathrm{H}_{18} \mathrm{O}_{5} \mathrm{Na}, 301.1051\right)$. The IR spectrum showed absorptions at 1760 ( $\gamma$-lactone), 1633, 1607, 1475, and 1452 (aromatic ring) $\mathrm{cm}^{-1}$. Fifteen signals in the ${ }^{13} \mathrm{C}$-NMR (DEPT) spectra were recognized including one ester carbonyl $C$-atom $(\delta 170.4)$, four aromatic quarternary $C$-atoms $(\delta 158.7,154.2,133.4$ and 110.2$)$ and two aromatic methines ( $\delta 133.5$ and 115.2). The remaining signals in the ${ }^{13} \mathrm{C}$-NMR spectra could be attributed to three

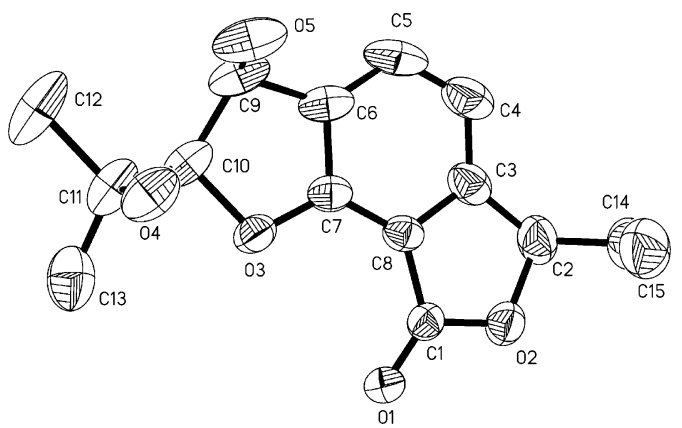

Fig. 1 Crystal structure of daldinin A (1) with crystallographic numbering pattern.

methyls $(\delta 8.8,26.5$ and 27.0), one methylene ( $\delta$ 28.7), three methines bearing an $O$-atom $(\delta 94.0,71.9$ and 84.3), and one quarternary carbon bearing an $O$-atom $(\delta 73.2)$. The ${ }^{1} \mathrm{H}-{ }^{1} \mathrm{H}$ COSY data allowed establishment of three $\mathrm{H}-$ atoms systems, one at $\mathrm{C}(2)$ through $\mathrm{C}(3)$, other two at $\mathrm{C}(4)$ through $C(5)$ and $C(6)$ through $C(10)$, by showing correlations between $\mathrm{H}-2$ and $\mathrm{H}-3$; H-4 and H-5; H-6 and $\mathrm{H}-9, \mathrm{H}-9$ and H-10. Combining with the information of HMBC, the basic skeleton of $\mathbf{1}$ was established. The structure of $\mathbf{1}$ was assigned by X-ray crystallographic analysis, which also offered information on the relative stereochemistry of $\mathbf{1}$ (Fig. 1). Thus, the structure of $\mathbf{1}$ was determined.

Daldinin B (2) was obtained as oily solid. Its molecular formula of $\mathrm{C}_{15} \mathrm{H}_{18} \mathrm{O}_{4}$ was established on the basis of EIMS, ${ }^{13} \mathrm{C}-\mathrm{NMR}$, and DEPT NMR spectra and confirmed by HR-ESI-MS (found 285.1099, calcd for $\mathrm{C}_{15} \mathrm{H}_{18} \mathrm{O}_{4} \mathrm{Na}$, 
285.1102). The IR spectrum showed absorptions at 1755 $(\gamma$-lactone), 1633, 1607, 1480, and 1450 (aromatic ring) $\mathrm{cm}^{-1}$. Fifteen signals in the ${ }^{13} \mathrm{C}-\mathrm{NMR}$ (DEPT) spectra were recognized including one ester carbonyl $C$-atom $(\delta 168.2)$, four aromatic quarternary $C$-atoms $(\delta 158.4,150.8,131.3$ and 108.8) and two aromatic methines ( $\delta 130.3$ and 113.6). The remaining signals in the ${ }^{13} \mathrm{C}$-NMR spectra could be attributed to three methyls $(\delta 9.0,25.6$ and 25.5), two methylenes $(\delta 29.8$, and 29.3), two methines bearing an $O$-atom ( $\delta 92.6$, and 82.4 ), and one quarternary carbon bearing an $O$-atom $(\delta 71.3)$. The ${ }^{1} \mathrm{H}-{ }^{1} \mathrm{H}$ COSY data allowed establishment of three $\mathrm{H}$-atoms systems, one at $\mathrm{C}-2$ through C-3, other two at C-4 through C-5 and C-6 through C-10, by showing correlations between $\mathrm{H}-2$ and $\mathrm{H}-3$; $\mathrm{H}-4$ and H-5; H-6 and H-9, H-9 and H-10. Combining with the information of HMBC, the basic skeleton of 2 was established, which is similar to $\mathbf{1}$. The structure of $\mathbf{1}$ was assigned by X-ray crystallographic analysis, which also offered information on the relative stereochemistry of 2 .

Daldinin C (3) was obtained as oily solid. The HR-EIMS together with the NMR data were used to determine the molecular formula of 3 to be $\mathrm{C}_{15} \mathrm{H}_{22} \mathrm{O}_{4}$, possessing four more hydrogen atoms than 2. Also, the ${ }^{1} \mathrm{H}$ - and ${ }^{13} \mathrm{C}$-NMR signals of $\mathbf{3}$ were virtually identical to those of $\mathbf{2}$. The absence of a signal for a carbonyl $\left(\delta_{\mathrm{C}} 168.2, \mathrm{~s}, \mathrm{C}-8\right)$ of $\mathbf{2}$, along with the observation of resonances for an additional oxygenated methyl $\left(\delta_{\mathrm{H}} 4.71,2 \mathrm{H}, \mathrm{s}, \mathrm{H}-8, \delta_{\mathrm{C}} 58.7, \mathrm{t}, \mathrm{C}-8\right)$, suggested the lack of a lactone ring in $\mathbf{3}$, a feature found in 2. Therefore, the structure of $\mathbf{3}$ was suggested.

The anti-HIV activity of daldinins $\mathrm{A} \sim \mathrm{C}$ was tested with reported method [9], the results were negative.

Acknowledgment This work was supported by National Natural Science Foundation of China (30470027) and grants of CAS (KSCX1-YW-R-24 and KSCX2-YW-G-025).

\section{References}

1. Henkel T, Brunne RM, Mueller H, Reichel F. Statistical investigation into the structural complementarity of natural products and synthetic compounds. Angew Chem Int Ed 38: 643-647 (1999)

2. Shu YZ. Recent natural products based drug development: a pharmaceutical industry perspective. J Nat Prod 61: 1053-1071 (1998)

3. Newman DJ, Cragg GM. Natural products as sources of new drugs over the last 25 years. J Nat Prod 70: 461-477 (2007)
4. Bode HB, Bethe B, Hoefs R, Zeeck A. Big effects from small changes: possible ways to explore nature's chemical diversity. ChemBioChem 3: 619-627 (2002)

5. Hoefs R, Walker M, Zeeck A. Hexacyclinic acid, a polyketide from Streptomyces with a novel carbon skeleton. Angew Chem Int Ed 39: 3258-3261 (2000)

6. Fuchser J, Zeeck A. Secondary metabolites by chemical screening, 34. aspinolides and aspinonene/aspyrone cometabolites, new pentaketides produced by Aspergillus ochraceus. Liebigs Ann 87-95 (1997)

7. Grond S, Papastavrou I, Zeeck A. Studies of precursordirected biosynthesis with Streptomyces, 3 structural diversity of 1-O-acyl $\alpha$-L-rhamnopyranosides by precursordirected biosynthesis with Streptomyces griseoviridis. Eur J Org Chem 1875-1881 (2000)

8. Sattler I, Thiericke R, Zeeck A. The manumycin-group metabolites. Nat Prod Rep 15: 221-240 (1998)

9. Qin XD, Dong ZJ, Liu JK, Yang LM, Wang RR, Zheng YT, Lu Y, Wu YS, Zheng QT. Concentricolide, an anti-HIV agent from the ascomycete Daldinia concentrica. Helv Chim Acta 89: 127-133 (2006)

10. Qin XD, Liu JK. Natural aromatic steroids as potential molecular fossils from the fruiting bodies of the ascomycete Daldinia concentrica. J Nat Prod 67: 2133-2135 (2004)

11. Qin XD, Dong ZJ, Liu JK. Two new compounds from the ascomycete Daldinia concentrica. Helv Chim Acta 89: 450-455 (2006)

12. Qin XD, Liu JK. Three new homologous 3-alkyl-1,4-benzoquinones from the fruiting bodies of Daldinia concentrica. Helv Chim Acta 87: 2022-2024 (2004)

13. Wang F, Liu JK. A pair of novel heptentriol stereoisomers from the ascomycete Daldinia concentrica. Helv Chim Acta 87: 2131-2134 (2004)

14. Kameoka H, Miyazawa M, Haze K. 3-Eethyl-7hydroxyphthalide from Forsythia japonica. Phytochemisty 14: 1676-1677 (1975)

15. Anderson JR, Edwards RL, Whalley AJS. Metabolites of the higher fungi. Part 21. 3-Methyl-3,4-dihydroisocoumarins and related compounds from the ascomycete family Xylariaceae. J Chem Soc Perkin Trans 1, 2185-2192 (1983)

16. Weber D, Gorzalczany S, Martino V, Acevedo C, Sterner O, Anke T. Metabolites from endophytes of the medicinal plant Erythrina crista-galli. Z Naturforsch 60c: 467-477 (2005) 